\title{
MODEL FOR TRACE METAL EXPOSURE IN FILTER-FEEDING FLAMINGOS AT ALKALINE RIFT VALLEY LAKE, KENYA
}

\author{
Yarrow M. Nelson, $†$ Ramesh J. Thampy, $\$$ G ideon K. Motelin,§ Jackson A. Raini,\$ \\ Cynthia J. DiSAnTe, $†$ and LeOnARD W. LiON*† \\ $\dagger$ School of Civil and Environmental Engineering, Cornell University, Ithaca, New York, 14853, USA \\ $\ddagger$ Lake Nakuru Conservation and Development Project, Worldwide Fund for Nature, P.O. Box 33, Nakuru, Kenya \\ $\S$ Department of Animal Health, Box 536, Egerton University, Njoro, Kenya
}

(Received 14 November 1997; Accepted 8 April 1998)

\begin{abstract}
Lake Nakuru, Kenya. Chromium $(\mathrm{Cr})$, copper $(\mathrm{Cu})$, lead $(\mathrm{Pb})$, and zinc $(\mathrm{Zn})$ have accumulated in the lake sediments as a result of unregulated discharges and because this alkaline lake has no natural outlet. Lesser flamingos (Phoeniconaias minor) at Lake Nakuru feed predominantly on the cyanobacterium Spirulina platensis, and because of their filter-feeding mechanism, they are susceptible to exposure to particlebound metals. Trace metal adsorption isotherms to lake sediments and S. platensis were obtained under simulated lake conditions, and a mathematical model was developed to predict metal exposure via filter feeding based on predicted trace metal phase distributions. Metal adsorption to suspended solids followed the trend $\mathrm{Pb} \gg \mathrm{Zn}>\mathrm{Cr}>\mathrm{Cu}$, and isotherms were linear up to 60 $\mu \mathrm{g} / \mathrm{L}$. Adsorption to $S$. platensis cells followed the trend $\mathrm{Pb} \gg \mathrm{Zn}>\mathrm{Cu}>\mathrm{Cr}$ and fit Langmuir isotherms for $\mathrm{Cr}, \mathrm{Cu}$ and $\mathrm{Zn}$ and a linear isotherm for $\mathrm{Pb}$. Predicted phase distributions indicated that $\mathrm{Cr}$ and $\mathrm{Pb}$ in Lake Nakuru are predominantly associated with suspended solids, whereas $\mathrm{Cu}$ and $\mathrm{Zn}$ are distributed more evenly between the dissolved phase and particulate phases of both $S$. platensis and suspended solids. Based on established flamingo feeding rates and particle size selection, predicted $\mathrm{Cr}$ and $\mathrm{Pb}$ exposure occurs predominantly through ingestion of suspended solids, whereas $\mathrm{Cu}$ and $\mathrm{Zn}$ exposure occurs through ingestion of both suspended solids and S. platensis. For the lake conditions at the time of sampling $(1.2 \mathrm{~g} / \mathrm{L}$ suspended solids, $0.23 \mathrm{~g} / \mathrm{L}$ S. platensis $)$, predicted ingestion rates based on measured metal concentrations in lake suspended solids were $0.71,6.2,0.81$, and $13 \mathrm{mg} / \mathrm{kg}$ - $\mathrm{d} \mathrm{for} \mathrm{Cr}$, Cu, $\mathrm{Pb}$, and $\mathrm{Zn}$, respectively. Higher exposure doses are predicted when metal concentrations are determined from sediment concentrations rather than suspended solids concentrations. Also, decreases in the S. platensis population would increase the clearing rate of the flamingos and increase predicted metal exposure via ingestion of suspended solids. For example, with metal concentrations calculated based on average metal concentrations in lake sediments and $S$. platensis concentration of $0.06 \mathrm{~g} / \mathrm{L}$, exposure rates would be 13 , $10,4.4$, and $38 \mathrm{mg} / \mathrm{kg}$-d for $\mathrm{Cr}, \mathrm{Cu}, \mathrm{Pb}$, and $\mathrm{Zn}$, respectively. These ingestion rates, except for $\mathrm{Cu}$, are significantly higher than the no observable adverse effects levels.
\end{abstract}

Keywords-Metal Toxicity Adsorption Filter feeding Flamingo

\section{INTRODUCTION}

In August-November 1993 and August-September 1995, 40,000 lesser flamingos (Phoeniconaias minor) died at Lake Nakuru, a saline, alkaline lake in a rapidly industrializing area of the Rift Valley in Kenya. Lake Nakuru National Park is the second most visited park in Kenya, and the main attraction of this park is the large flock of resident $P$. minor, making these flamingos an important asset to Kenya's tourism industry. Necropsies of killed flamingos revealed liver histopathology including iron pigments in hepatocytes as well as scattered single cell necrosis and portal hepatitis [1]. These observations, although nonspecific, strongly indicate that toxicosis was one of the most likely causes of the flamingo deaths. Both hepatotoxic algae and toxic metals have been detected at Lake Nakuru and are potential causes of the observed liver damage. Although other studies are under way to investigate the potential pathological role of algal toxins, this study seeks to estimate the potential for toxic trace metal exposure to the flamingos at Lake Nakuru.

X-ray fluorescence spectroscopic analyses of Lake Nakuru sediments indicated that chromium $(\mathrm{Cr})$, copper $(\mathrm{Cu})$, lead $(\mathrm{Pb})$, and zinc $(\mathrm{Zn})$ are present in relatively high concentrations, whereas mercury $(\mathrm{Hg})$, selenium $(\mathrm{Se})$, and nickel $(\mathrm{Ni})$

\footnotetext{
* To whom correspondence may be addressed (1w13@ cornell.edu).
}

were almost always below detection limits. The metals detected in the lake sediments presumably are the result of unregulated discharges from local industries (e.g., tanneries, electroplating facilities, textile mills, battery factories, and paint packaging). A key question is if these toxic trace metals exist in the lake in forms that are likely to be consumed by the flamingos. The object of this study was to determine the phase distribution of the metals of concern in Lake Nakuru and to develop a model for estimating metal exposure doses to the flamingos feeding at Lake Nakuru. Lesser flamingos are filter feeders, feeding by stirring up lake sediments and filtering out planktonic phototrophs such as Spirulina platensis [2]. This feeding mechanism makes the flamingos particularly susceptible to toxic metals that are associated with their planktonic food and with suspended solids that are inadvertently filtered and consumed. In the current work, adsorption isotherms (adsorbed metal as a function of dissolved metal concentration) were determined for the metals of concern for both suspended solids obtained from Lake Nakuru and for S. platensis, which is the primary food source of the flamingos [2-5]. An exposure model was developed using these adsorption isotherms to predict trace metal phase distributions in the Lake Nakuru water column under the dynamic physicochemical and biological conditions in the lake. Because lesser flamingos do not drink 
Table 1. Concentrations of major ions in the Lake Nakuru water column $^{\mathrm{a}}$

\begin{tabular}{lclc}
\hline Anion & $\begin{array}{c}\text { Concentration } \\
(\mathrm{mg} / \mathrm{L})\end{array}$ & Cation & $\begin{array}{c}\text { Concentration } \\
(\mathrm{mg} / \mathrm{L})\end{array}$ \\
\hline $\mathrm{SO}_{4}{ }^{2-}$ & 62 & $\mathrm{Na}^{+}$ & 3,300 \\
$\mathrm{Cl}^{-}$ & 1,020 & $\mathrm{~K}^{+}$ & 237 \\
$\mathrm{HCO}^{-}$ & 3,200 & $\mathrm{Ca}^{2+}$ & 0 \\
$\mathrm{CO}_{3}{ }^{2-}$ & 4,100 & $\mathrm{Mg}^{2+}$ & 0.9 \\
$\mathrm{PO}_{4}{ }^{3-}$ & 13.6 & & \\
$\mathrm{~F}^{-}$ & 129 & & \\
\hline
\end{tabular}

a $[8,9]$.

alkaline lake water but instead drink from nearby freshwater springs or rivers $[2-4,6,7]$, they could also be exposed to toxic metals in freshwater sources. Metal exposure from freshwater sources is potentially significant, but these sources are diverse, with varying metal concentrations, and their analysis and use by $P$. minor was not within the scope of this work.

Lake Nakuru is highly alkaline, with high concentrations of $\mathrm{Na}^{+}, \mathrm{Cl}^{-}, \mathrm{HCO}_{3}^{-}$and $\mathrm{CO}_{3}^{2-}$ (Table 1, after [8,9]), and this unique chemistry is expected to strongly influence the adsorption behavior of the metals of interest. Adsorption isotherms were therefore measured under solution conditions chosen to match those of Lake Nakuru. This semiempirical method of using site-specific adsorption experiments to model trace metal phase distribution has been successfully applied to a number of freshwater lakes [10-14] and marine environments [15]. The phase distribution model was then combined with physiological data for the flamingos (e.g., feeding rate, particle size retention) and water quality parameters for the lake (e.g., suspended solids concentration, $S$. platensis concentration) to estimate total metal ingestion rates for a range of conditions.

Ultimately, full assessment of the threat of toxic metals to the flamingos at Lake Nakuru will require toxicodynamic modeling of metal uptake and a toxicological effects assessment in addition to the estimation of exposure doses presented here. Such a risk assessment model could be used both in a retrospective analysis to determine the potential role of toxic metals in the past flamingo kills and for a predictive analysis to determine acceptable discharge rates of toxic metals from industrial and agricultural activities in the watershed. Information from the risk assessment could also be used in conjunction with a toxic release inventory to guide implementation of remedial programs such as industrial waste minimization projects, improvements to wastewater treatment systems, development of hazardous waste disposal protocols, and agricultural soil conservation programs. The work presented here is the first step in developing a complete risk assessment model and includes an evaluation of exposure pathways and development of a model to predict exposure doses via filter feeding for each of the metals of concern $(\mathrm{Cr}, \mathrm{Cu}, \mathrm{Pb}$, and $\mathrm{Zn})$. In addition to evaluating the potential for exposure of the flamingos to toxic metals, investigation of metal behavior under the conditions of the alkaline chemistry of this lake provides insight for modeling trace metal interactions in other alkaline aquatic environments.

\section{METHODS}

Sediment samples were collected in March 1996 from 11 sites when the lake level was low enough to permit direct collection of dry sediments. Trace metal concentrations in sediments were measured using X-ray fluorescence spectroscopy by the University of Nairobi Institute of Nuclear Science (Nairobi, Kenya).

Lake water samples were collected in April 1996 using acid-washed polyethylene sample bottles. Water samples were collected at locations while flamingos were feeding so that water samples were representative of water actually filtered by the flamingos during feeding. Standard methods [16] were used for determination of total suspended solids (TSS, method 2540 D), volatile suspended solids (VSS, method $2540 \mathrm{E}$ ), and alkalinity (method $2320 \mathrm{~B}$ ). Concentrations of S. platensis were determined by microscopic counting of cells at $150 \times$, and $S$. platensis biomass was estimated by measuring chlorophyll $a$ spectrophotometrically (standard method $10200 \mathrm{H}$ [16]).

Trace metals associated with Lake Nakuru suspended solids in the April 1996 samples were determined on a dry weight basis by atomic absorption spectroscopy (AAS) of acid-digested samples. Four samples of filtered and dried solids were digested by adding $50 \mathrm{ml}$ of $15 \% \mathrm{HNO}_{3}$ (glass distilled, GFS Chemicals, Columbus, OH, USA) to $5 \mathrm{~g}$ of sample. Trace metals $(\mathrm{Pb}, \mathrm{Cu}, \mathrm{Cr}$, and $\mathrm{Zn})$ were spiked into one of the samples at $10 \mu \mathrm{g} / \mathrm{g}$ to determine recovery. Samples were refluxed for $1 \mathrm{~h}$, cooled, diluted to $50 \mathrm{ml}$ with distilled-deionized water, and filtered through $0.45-\mu \mathrm{m}$ polyvinyldiflouride (PVDF) membranes (Millipore, Bedford, MA, USA). Zinc was analyzed by AAS using a Perkin-Elmer AAnalyst 100 (Norwalk, $\mathrm{CT}$, USA). Chromium, $\mathrm{Cu}$, and $\mathrm{Pb}$ were analyzed by graphite furnace atomic absorption spectrophotometry (GFAAS) using a model 460 AA equipped with a Model HGA-2100 graphite furnace (Perkin-Elmer, Norwalk, CT, USA). Prior to GFAAS analysis, samples were diluted with distilled-deionized water (10 to $50 \times$ ) to reduce observed matrix effects, and the method of standard additions was used to account for any remaining matrix effects. Because matrix effects were severe for $\mathrm{Pb}$ analysis by GFAAS, samples for $\mathrm{Pb}$ analysis were adjusted to $\mathrm{pH}$ 3.0, chelated with ammonium pyrrolidine dithiocarbamate (APDC), and extracted into methyl isobutyl ketone (MIBK) (Standard Method \#3111C, [16]). Following extraction, solutions were analyzed with GFAAS as described above.

Isotherms were obtained under simulated Lake Nakuru conditions for trace metal $(\mathrm{Pb}, \mathrm{Cr}, \mathrm{Cu}$, and $\mathrm{Zn})$ adsorption to suspended solids collected from Lake Nakuru and to S. platensis grown in pure culture. Lake conditions were simulated by collecting trona salts at the lake when the lake was dry and dissolving these salts in distilled-deionized water at a level approximately equivalent to the total dissolved solids concentration in the lake $(5 \mathrm{~g} / \mathrm{L})$. The $\mathrm{pH}$ of these solutions was 10.0 \pm 0.1 , without any adjustment, and this was the same as that measured at the lake. Suspended solids were obtained from the lake in March 1996 and dried for storage. Spirulina platensis was obtained in pure culture from the UTEX algal culture collection (UTEX Culture \# LB-2340, University of Texas, Austin, TX, USA) and was originally isolated from an African alkaline lake near Lake Nakuru. Spirulina platensis was grown in an alkaline medium (Table 2) under fluorescent lights to a final cell density of 0.15 to $0.4 \mathrm{~g}$ dry wt per liter. For adsorption experiments, the algal growth medium (which contains trace metals, $\mathrm{PO}_{4}^{3-}$ and EDTA, all of which could interfere with metal adsorption) was rinsed from the cell suspensions by repetitive $(3 \times)$ centrifuging, decanting, and resuspending with the simulated lake water. Metal adsorption was measured by preparing solutions in simulated lake water with a range of dissolved 
Table 2. Growth medium for Spirulina platensis used in adsorption experiments

\begin{tabular}{|c|c|c|}
\hline Solution $^{\mathrm{a}}$ & Component & $\begin{array}{c}\text { Concentration } \\
(\mathrm{g} / \mathrm{L})\end{array}$ \\
\hline & $\mathrm{NaHCO}_{3}$ & 13.6 \\
\hline \multirow{3}{*}{ A } & $\mathrm{Na}_{2} \mathrm{CO}_{3}$ & 4.0 \\
\hline & $\mathrm{K}_{2} \mathrm{HPO}_{4}$ & 0.5 \\
\hline & $\mathrm{NaNO}_{3}$ & 2.5 \\
\hline \multirow[t]{4}{*}{$\mathrm{B}^{\mathrm{b}}$} & $\mathrm{K}_{2} \mathrm{SO}_{4}$ & 1.0 \\
\hline & $\mathrm{NaCl}$ & 1.0 \\
\hline & $\mathrm{MgSO}_{4} \cdot 7 \mathrm{H}_{2} \mathrm{O}$ & 0.20 \\
\hline & $\mathrm{CaCl}_{2} \cdot 2 \mathrm{H}_{2} \mathrm{O}$ & 0.04 \\
\hline \multirow[t]{6}{*}{ PIV metal stock } & $\mathrm{Na}_{2}$ EDTA & 0.75 \\
\hline & $\mathrm{FeCl}_{3} \cdot 6 \mathrm{H}_{2} \mathrm{O}$ & 0.097 \\
\hline & $\mathrm{MnCl}_{2} 4 \mathrm{H}_{2} \mathrm{O}$ & 0.041 \\
\hline & $\mathrm{ZnCl}_{2}$ & 0.005 \\
\hline & $\mathrm{CoCl}_{2} \cdot 6 \mathrm{H}_{2} \mathrm{O}$ & 0.002 \\
\hline & $\left(\mathrm{NH}_{4}\right)_{6} \mathrm{Mo}_{7} \mathrm{O}_{24}$ & 0.004 \\
\hline \multirow[t]{7}{*}{ Micronutrient stock } & $\mathrm{Na}_{2}$ EDTA & 0.050 \\
\hline & $\mathrm{H}_{3} \mathrm{BO}_{3}$ & 0.62 \\
\hline & $\mathrm{CuSO}_{4} \cdot 5 \mathrm{H}_{2} \mathrm{O}$ & 0.020 \\
\hline & $\mathrm{ZnSO}_{4} \cdot 7 \mathrm{H}_{2} \mathrm{O}$ & 0.044 \\
\hline & $\mathrm{CoCl}_{2} \cdot 6 \mathrm{H}_{2} \mathrm{O}$ & 0.020 \\
\hline & $\mathrm{MnCl}_{2} \cdot 4 \mathrm{H}_{2} \mathrm{O}$ & 0.013 \\
\hline & $\mathrm{Na}_{2} \mathrm{MoO}_{4} \cdot 2 \mathrm{H}_{2} \mathrm{O}$ & 0.013 \\
\hline
\end{tabular}

a To prevent precipitates from forming during autoclaving, the components of solutions A and B were autoclaved separately and combined aseptically (1:1 volume ratio) after cooling.

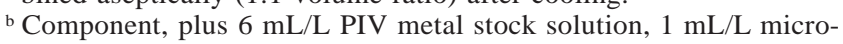
nutrient stock solution, and $1 \mathrm{~mL} / \mathrm{L}$ vitamin B12 solution $(150 \mu \mathrm{g} /$ L).

metal concentrations $(0.2-2.0 \mu \mathrm{M})$. These solutions were placed in 25-ml Teflon ${ }^{\circledR}$ centrifuge tubes, with and without sediment or $S$. platensis present, and equilibrated for $24 \mathrm{~h}$ at $24^{\circ} \mathrm{C}$. Solutions without adsorbent were prepared for each metal concentration to serve as controls and standards. After equilibration, the solutions were centrifuged at $10,700 \mathrm{~g}$ for $10 \mathrm{~min}$ and then filtered with $0.4-\mu \mathrm{m}$ retention polycarbonate filters (Millipore). Because the standards were also filtered, losses due to filtration as well as matrix effects were intrinsically accounted for. The observed metal loss due to filtration was less than $5 \%$.

The size distribution of Lake Nakuru suspended solids was determined by resuspending dried solids into simulated lake water and counting suspended particles with a Coulter Multisizer II (Coulter Electronics, Luton, Beds, UK), equipped with a $100 \mu \mathrm{m}$ orifice, and operated at an aperture current of $1,500 \mu \mathrm{A}$. For each analysis, $100 \mu \mathrm{l}$ samples of suspensions were diluted with $20 \mathrm{ml}$ of an isotonic solution (Isoton II, Coulter Diagnostics, Luton, Beds, UK).

\section{RESULTS}

\section{Lake Nakuru chemistry}

The $\mathrm{pH}$ of Lake Nakuru was consistently 10.0 during the study period in March and April 1996. The temperature of the lake was $29 \pm 1{ }^{\circ} \mathrm{C}$, conductivity was 50 to $60 \mathrm{mS} / \mathrm{cm}$, and the total dissolved solids (TDS) concentration was 5 to $60 \mathrm{~g} / \mathrm{L}$. The lake was strongly buffered, with an alkalinity of up to $0.95 \mathrm{eq} / \mathrm{L}$. Total suspended solids concentrations ranged from 1.2 to $1.5 \mathrm{~g} / \mathrm{L}$, with corresponding volatile suspended solids (VSS) concentrations of 0.51 to $0.62 \mathrm{~g} / \mathrm{L}$. The phototrophic
Table 3. Trace metal concentrations in Lake Nakuru sediments (by X-ray fluorescence spectroscopy) and in Lake Nakuru suspended solids (by GFAAS for chromium, copper, and lead and AAS for zinc) $)^{\mathrm{a}}$

\begin{tabular}{lccccc}
\hline & \multicolumn{2}{c}{$\begin{array}{c}\text { Concentration in } \\
\text { dry sediments }(\mu \mathrm{g} / \mathrm{g})\end{array}$} & & \multicolumn{2}{c}{$\begin{array}{c}\text { Concentration in } \\
\text { suspended solids }(\mu \mathrm{g} / \mathrm{g})\end{array}$} \\
\cline { 2 - 3 } \cline { 5 - 6 } $\begin{array}{l}\text { Trace } \\
\text { metal }\end{array}$ & $\begin{array}{c}\text { Average } \\
(11 \text { sites })^{\mathrm{b}}\end{array}$ & Range & & Average & $\begin{array}{c}\text { Standard } \\
\text { deviation }\end{array}$ \\
\hline Chromium & 67 & $10-280$ & & 8.3 & 0.82 \\
Copper & 24 & $5-95$ & & 19 & 2.9 \\
Lead & 22 & $4-100$ & & 11.7 & 0.9 \\
Zinc & 147 & $44-630$ & & 74 & 31 \\
\hline
\end{tabular}

${ }^{\text {a }}$ GFAAS = graphite furnace atomic absorption spectrophotometry; AAS = atomic absorption spectroscopy. All metal concentrations are reported on a dry weight basis.

b Arithmetic mean.

community was almost exclusively $S$. platensis at a concentration of approximately $0.23 \mathrm{~g} / \mathrm{L}$.

Trace metals in Lake Nakuru sediments and suspended solids

Trace metal concentrations in Lake Nakuru sediments, as determined by X-ray fluorescence spectroscopy, varied over an order of magnitude for each of the metals for dry sediment samples collected at 11 sites (Table 3). Copper, $\mathrm{Pb}$, and $\mathrm{Zn}$ concentrations in suspended solids (determined using acid extractions and GFAAS) collected from Lake Nakuru were slightly lower than average concentrations in sediments, whereas the $\mathrm{Cr}$ concentration in the suspended solids was much lower than the average for the sediments (Table 3).

\section{Adsorption isotherms}

Adsorption isotherms for metal adsorption to Lake Nakuru sediments in reconstituted lake water at $\mathrm{pH} 10.0$ were linear for all four metals with respect to dissolved metal concentration over the range of concentrations considered, and distribution coefficients $\left(K_{\mathrm{d}}\right)$ were calculated for each metal (Fig. 1). Adsorption to sediments followed the trend $\mathrm{Pb} \gg \mathrm{Zn}>$ $\mathrm{Cr}>\mathrm{Cu}$, with adsorption of $\mathrm{Pb}$ to sediment over an order of magnitude greater than that of the other metals.

Adsorption to $S$. platensis followed the trend $\mathrm{Pb} \gg \mathrm{Zn}>$ $\mathrm{Cu}>\mathrm{Cr}$, with $\mathrm{Pb}$ adsorption again an order of magnitude greater than that of the other metals (Fig. 2). Adsorption of $\mathrm{Cr}, \mathrm{Cu}$, and $\mathrm{Zn}$ to $\mathrm{S}$. platensis followed Langmuir isotherms (Fig. 2A, B, and D) of the form $\Gamma=\Gamma_{\max } \cdot K \cdot \mathrm{C} /(1+\mathrm{K} \cdot \mathrm{C})$, where $\Gamma=$ metal adsorption at dissolved metal concentration $\mathrm{C}, \Gamma_{\max }=$ maximum metal adsorption, and $K=$ the Langmuir equilibrium constant. The $\mathrm{Pb}$ adsorption isotherm was taken as linear (Fig. 2C).

\section{Predicted metal phase distributions}

Isotherms for $\mathrm{Pb}, \mathrm{Cr}, \mathrm{Cu}$, and $\mathrm{Zn}$ adsorption to Lake Nakuru sediments and to $S$. platensis (at $\mathrm{pH} 10.0$ ) were used to estimate trace metal phase distributions in the Lake Nakuru water column under the conditions described previously. Concentrations of metals associated with suspended solids (Table 3 , column 4) were used to calculate the dissolved concentration of each metal by assuming equilibrium using the isotherms in Figure 1. Trace metal adsorption to $S$. platensis was then calculated 

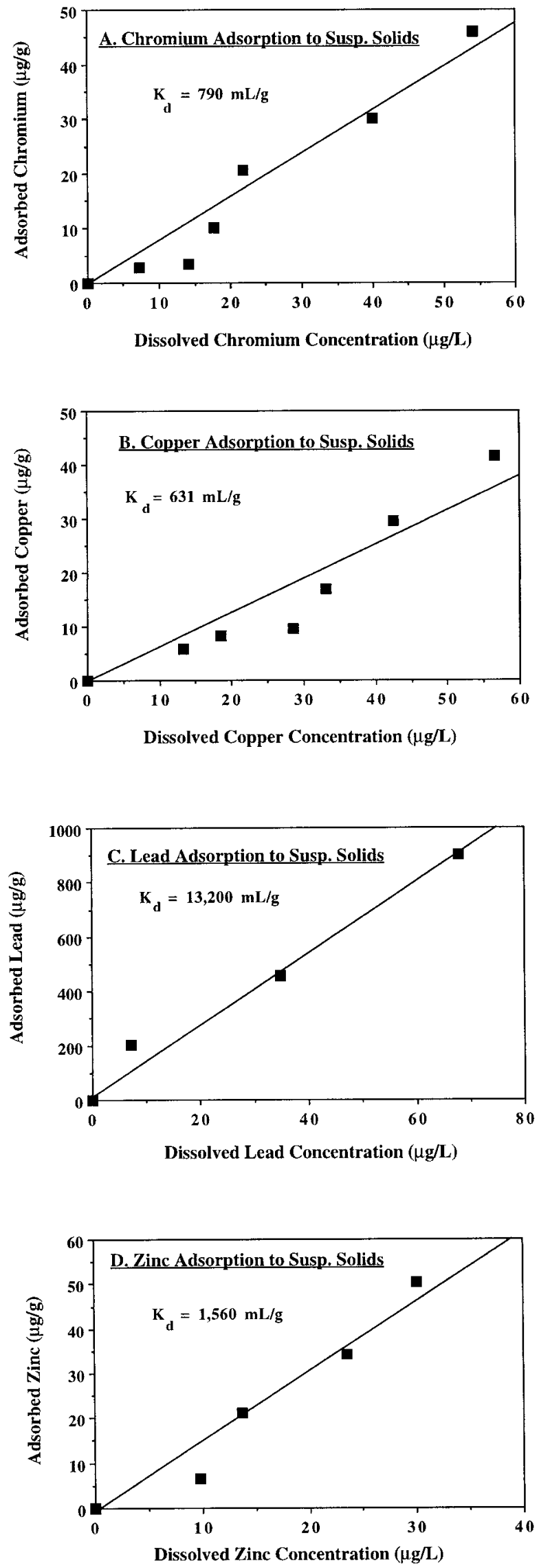

FIG. 1. Adsorption isotherms for trace metal adsorption to L. Nakuru suspended solids under simulated Lake Nakuru conditions $(\mathrm{pH}=$ 10.0). Chromium (A), copper (B), lead (C), and zinc (D). using the adsorption isotherms in Figure 2. Metal phase distributions were calculated based on a suspended solids concentration of $1.2 \mathrm{~g} / \mathrm{L}$ and a $S$. platensis concentration of 0.23 $\mathrm{g} / \mathrm{L}$ and are shown in Figure 3. Greater than $90 \%$ of total $\mathrm{Pb}$ in the water column was estimated to be associated with suspended solids. Chromium was equally distributed between the suspended solids phase and the dissolved phase, with little $\mathrm{Cr}$ associated with $S$. platensis. Copper and $\mathrm{Zn}$ were present in significant concentrations in all three phases (Fig. 3). Note that the metal concentrations shown in Figure 3 are based on trace metals associated with suspended solids measured at a single site (Table 3, column 4), and that higher metal concentrations would be calculated based on average metal concentrations in dry sediments (Table 3, columns 2 and 3 ).

\section{Model for exposure of flamingos to trace metals via filter-feeding}

The overall rate of metal ingestion via filter feeding $\left(U_{T}\right)$ can be calculated as the sum of exposure via direct ingestion of metals bound to $S$. platensis and metals bound to suspended sediments:

$$
U_{T}(t)=U_{S p}(t)+U_{T S S}(t)
$$

where $U_{S p}(t)=$ the rate of metal exposure by feeding on $S$. platensis (units $=$ mass/time) and $U_{T S S}(t)=$ the rate of metal exposure via ingestion of suspended solids (TSS).

The rate of exposure by feeding on $S$. platensis, $U_{S p}(t)$, depends on the feeding rate $\left(F_{S p}, \mathrm{mg}\right.$ dry wt/kg-day) and the concentration of metal associated with $S$. platensis $\left(C_{M e, S p}, \mu \mathrm{g} / \mathrm{g}\right.$ S. platensis):

$$
U_{S p}(t)=C_{M e, S p} F_{S p}
$$

$U_{S p}(t)$ can thus be obtained by calculating $C_{M e, S p}$ from adsorption isotherms and using an established value for the flamingo feeding rate $\left(F_{S p}\right)$. Vareschi reported a feeding rate for $P$. minor on $S$. platensis of $72 \mathrm{~g} \mathrm{dr}$ wt/d per adult bird and an average weight of $1.8 \mathrm{~kg}$ per bird [5], giving a value of $F_{S p}$ of $40 \mathrm{~g} /$ kg-d.

The rate of uptake of metal associated with TSS depends on the total volumetric feeding rate of the flamingos $\left(F_{V}\right)$, the TSS concentration (TSS), and the equilibrium concentration of metal associated with TSS $\left(C_{M e, T S S}, \mu\right.$ mol metal per gram TSS). However, not all suspended solids are retained and ingested during filter feeding. Phoeniconaias minor use a combination of excluders and fine lamellar filters to retain particles with a size range of 20 to $100 \mu \mathrm{m}$ [2]. The flamingos are therefore specifically susceptible to trace metals adsorbed to TSS in this size range, and total metal uptake via suspended solids depends on the fraction of TSS in the 20- to $100-\mu \mathrm{m}$ size range $\left(f_{20-100}\right)$ :

$$
U_{T S S}(t)=C_{M e, T S S} F_{V} T S S f_{20-100} .
$$

Implicit in Equation 3 is the assumption that specific surface area and therefore specific metal binding capacity of suspended sediments is constant over the relevant range of particle sizes.

The volumetric clearing rate $(\mathrm{L} / \mathrm{kg}-\mathrm{d}), F_{V}$, can be determined from the $S$. platensis feeding rate and the concentration of $S$. platensis because

$$
F_{S p}=F_{V} C_{S p},
$$

where $C_{S p}=$ the concentration of suspended $S$. platensis. Thus, 

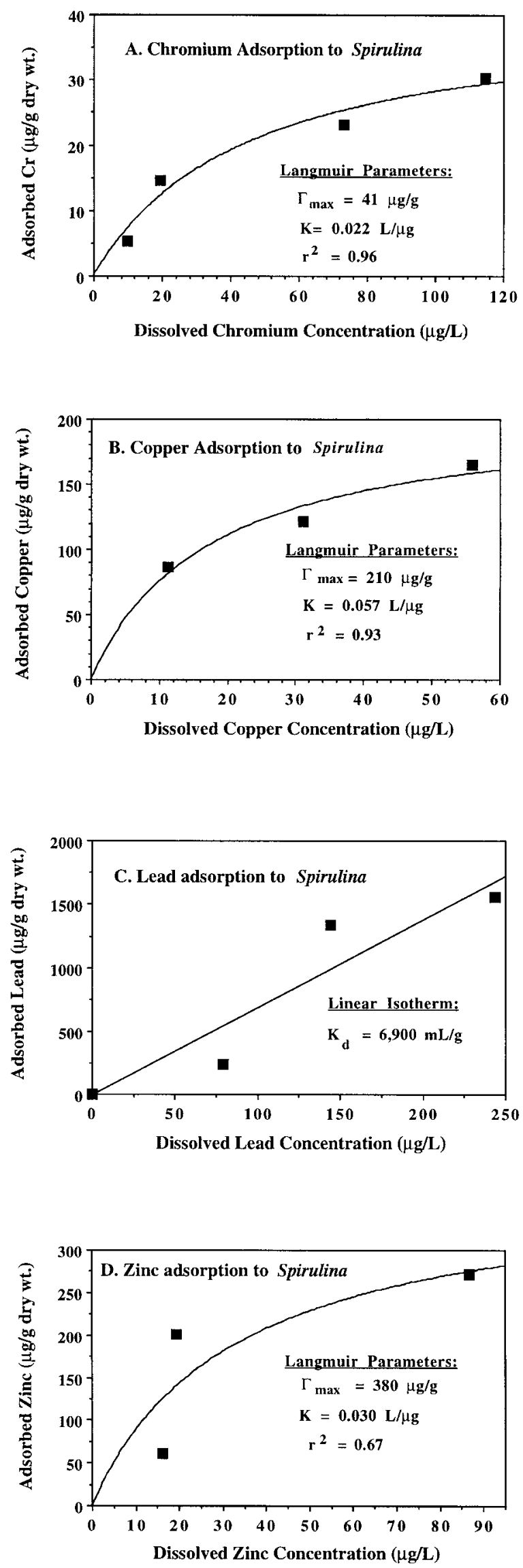

FIG. 2. Adsorption isotherms for trace metal adsorption to cells of Spirulina platensis under simulated Lake Nakuru conditions $(\mathrm{pH}=$ 10.0). Chromium (A), copper (B), lead (C), and zinc (D).

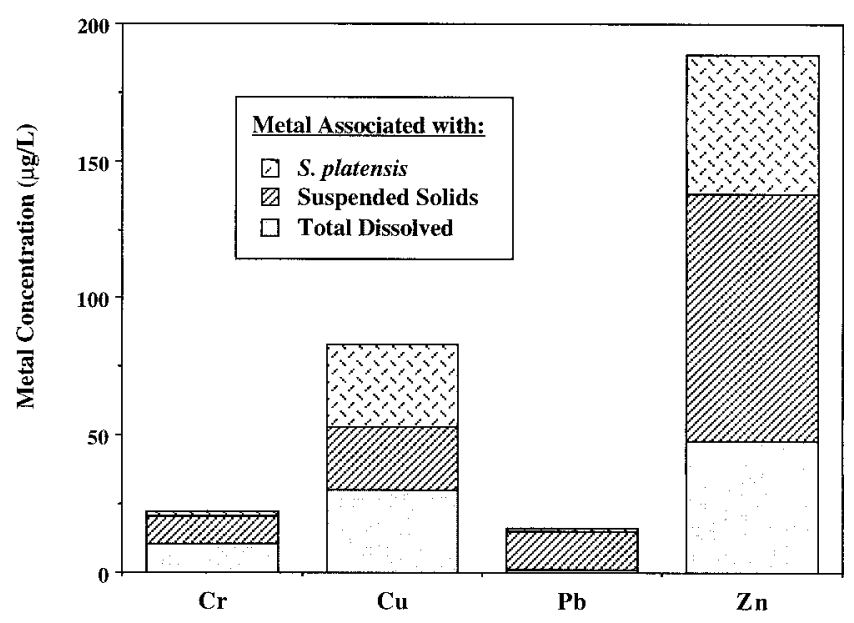

Fig. 3. Predicted trace metal phase distributions in Lake Nakuru for a total suspended solids concentration of $1.2 \mathrm{~g} / \mathrm{L}$ and a Spirulina platensis concentration of $0.23 \mathrm{~g} / \mathrm{L}$ at $\mathrm{pH}$ 10.0. Trace metal concentrations for this example were calculated from trace metal analysis of suspended solids collected in April 1996.

by solving for $F_{V}$ and substituting into Equation 3, metal uptake via TSS can be expressed as

$$
U_{T S S}(t)=C_{M e, T S S} T S S f_{20-100}\left(F_{S p} / C_{S p}\right) .
$$

Finally, by substituting Equations 2 and 5 into Equation 1, the total metal ingestion rate via filter feeding is given by

$$
U_{T}(t)=C_{M e, S P} F_{S p}+C_{M e, T S S} T S S f_{20-100}\left(F_{S p} / C_{S p}\right) .
$$

Because of the efficiency of the filter-feeding mechanism of $P$. minor [2], ingestion of entrained water is not considered likely to contribute significantly to total metal exposure.

\section{Exposure model predictions}

The exposure model was first applied to conditions prevalent at the time of water analyses conducted at Lake Nakuru in April 1996. At this time, the TSS concentration was $1.2 \mathrm{~g} / \mathrm{L}$, and the Spirulina concentration was $0.23 \mathrm{~g} / \mathrm{L}$. For a $S$. platensis concentration of $0.23 \mathrm{~g} / \mathrm{L}$ and a feeding rate $\left(F_{S p}\right)$ of 40 $\mathrm{g} / \mathrm{kg}$-d, the clearing rate $\left(F_{V}\right)$ would be about $170 \mathrm{~L} / \mathrm{kg}$-d (from Eqn. 4). From the size distribution of suspended solids in Lake Nakuru (Fig. 4), approximately $23 \%$ of TSS was in the 20- to $100-\mu \mathrm{m}$ size range, so $f_{20-100}=0.23$. For a first approximation,

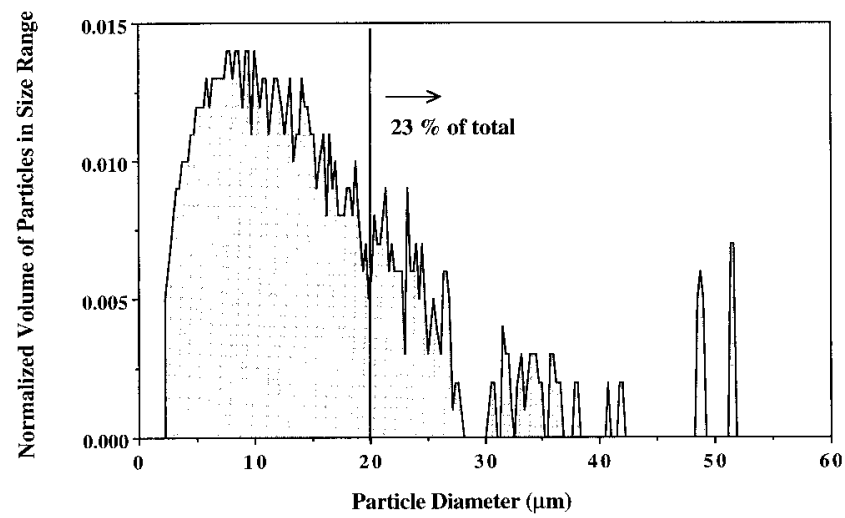

Fig. 4. Size distribution of suspended sediments in Lake Nakuru. 

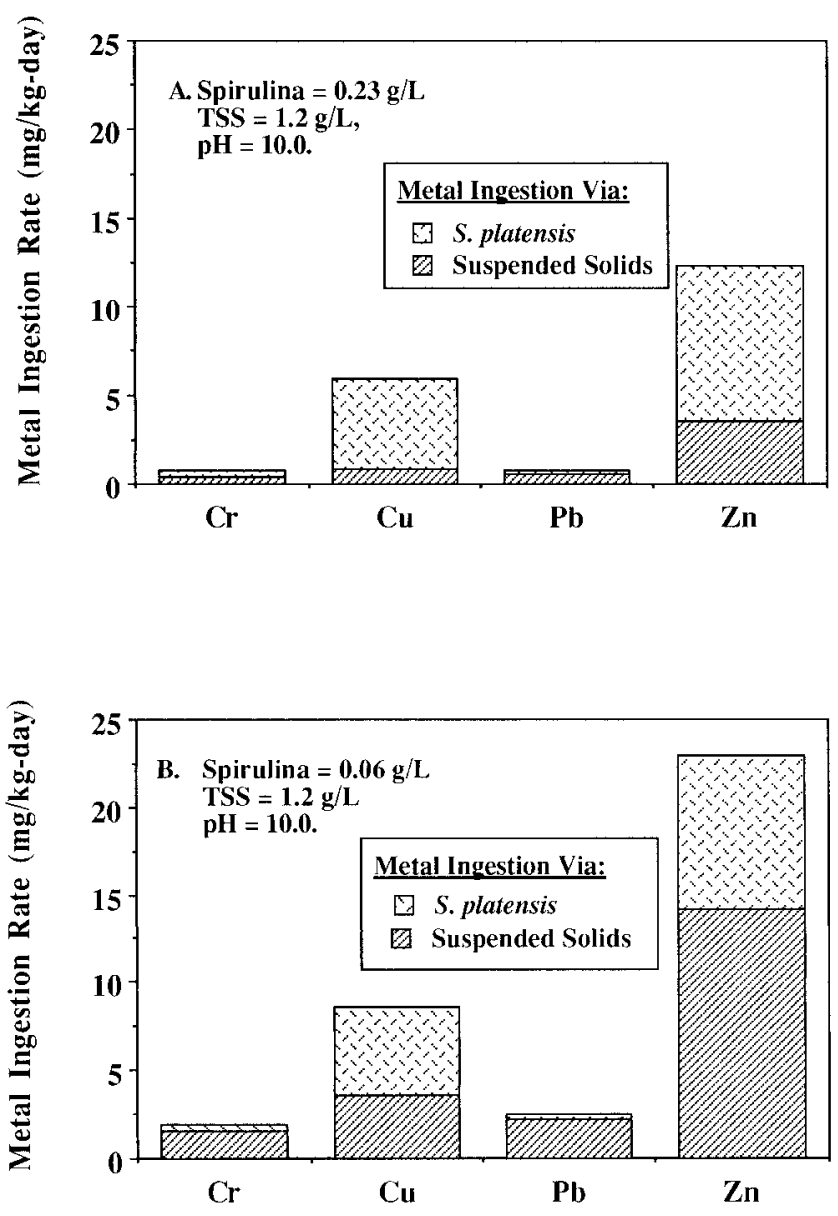

Fig. 5. Predicted toxic metal exposures doses via filter-feeding of Spirulina platensis and suspended solids. High S. platensis concentration $(230 \mathrm{mg} / \mathrm{L})(\mathbf{A})$. Low S. platensis concentration $(60 \mathrm{mg} / \mathrm{L})$ (B). Trace metal concentrations for this example were calculated from trace metal analysis of suspended solids collected in April 1996.

the model assumes that trace metal adsorption is similar on a weight basis for all particles.

Two different methods were used for calculating metal concentrations, one based on metal concentrations measured on suspended solids collected from a single site (Table 3, column 4) and one based on the average metal concentrations in dried sediments from 11 sites (Table 3, column 2). For calculations based on metal concentrations in suspended solids, the predicted trace metal phase distributions shown in Figure 3 apply. Under these conditions, $C_{M e, S p}$ was $7.8,130,6.1$, and $220 \mu \mathrm{g} /$ $\mathrm{g}$ for $\mathrm{Cr}, \mathrm{Cu}, \mathrm{Pb}$, and $\mathrm{Zn}$, respectively. $C_{M e, T S S}$ was obtained for each metal using the values in Table 3 (column 4). Metal exposure rates via $S$. platensis and TSS ingestion for this case were calculated using Equation 6 (Fig. 5A and Table 4, case 1). For this example, predicted $\mathrm{Cr}$ and $\mathrm{Pb}$ exposures were mostly via ingestion of suspended solids, whereas predicted $\mathrm{Cu}$ and $\mathrm{Zn}$ exposures were mostly via ingestion of $S$. platensis (Fig. 5A).

Because of the greater metal concentrations measured on lake sediments (Table 3, column 2), significantly higher exposure rates were calculated when these concentrations were used to calculate metal concentrations associated with solids and $S$. platensis (Table 4, case 2). The relative contributions
Table 4. Calculated trace metal exposure rates for four cases compared to no adverse effects levels (NOAEL) for birds

\begin{tabular}{|c|c|c|c|c|c|}
\hline \multirow[b]{3}{*}{ Metal } & \multicolumn{4}{|c|}{$\begin{array}{l}\text { Total calculated metal } \\
\text { exposure rate }(\mathrm{mg} / \mathrm{kg}-\mathrm{d})^{\mathrm{a}}\end{array}$} & \multirow{3}{*}{$\begin{array}{l}\text { NOAEL [19] } \\
(\mathrm{mg} / \mathrm{kg}-\mathrm{d})\end{array}$} \\
\hline & \multicolumn{2}{|c|}{$\begin{array}{c}\text { S. platensis } \\
\mathrm{g} / \mathrm{L}\end{array}$} & \multicolumn{2}{|c|}{$\begin{array}{c}\text { S. platensis }=0.06 \\
\mathrm{~g} / \mathrm{L}\end{array}$} & \\
\hline & Case 1 & Case 2 & Case 3 & Case 4 & \\
\hline Chromium & 0.71 & 4.5 & 1.8 & 13.1 & 1.0 \\
\hline Copper & 6.2 & 6.8 & 8.7 & 10.1 & 47 \\
\hline Lead & 0.81 & 1.5 & 2.4 & 4.4 & 1.1 \\
\hline Zinc & 13 & 18 & 23 & 38 & 15 \\
\hline
\end{tabular}

${ }^{a}$ Case 1: Metal concentrations calculated based on suspended solids analyses for a single site, Spirulina platensis $=0.23 \mathrm{~g} / \mathrm{L}$ (corresponds to Fig. 5A); Case 2: Metal concentrations calculated based on sediment analyses for 11 sites, S. platensis $=0.23 \mathrm{~g} / \mathrm{L}$; Case 3: Metal concentrations calculated based on suspended solids analyses for a single site, S. platensis $=0.06 \mathrm{~g} / \mathrm{L}$ (corresponds to Fig. $5 \mathrm{~B}$ ); Case 4: Metal concentrations calculated based on sediment analyses for 11 sites, $S$. platensis $=0.06 \mathrm{~g} / \mathrm{L}$. Total suspended $=1.2 \mathrm{~g} / \mathrm{L}$ for all cases.

of inert solids and $S$. platensis to total metal exposure were similar to those depicted in Figure 5A.

Decreases in $S$. platensis concentration are expected to increase metal ingestion rates via ingestion of suspended solids because the clearing rate would increase to compensate for the low feed concentration. Such decreases in S. platensis are likely to follow periods of rapid evaporation in the lake [17]. For example, if the $S$. platensis concentration decreased by a factor of four, from 0.23 to $0.06 \mathrm{~g} / \mathrm{L}$ (as has been observed at Lake Nakuru), the flamingos would have to increase their clearing rate by a factor of four to consume the same quantity of $S$. platensis. Such an increase in clearing rate would result in a fourfold increase in metal uptake predicted via ingestion of metals bound to suspended solids, significantly increasing predicted metal exposure rates (Fig. 5B and Table 4, cases 3 and 4). To illustrate this effect in more detail, predicted metal exposure rates are shown as a function of suspended $S$. platensis concentration in Figure 6. All four metals show a marked increase in exposure with decreasing $S$. platensis concentration. At a suspended $S$. platensis concentration of about 0.12 $\mathrm{g} / \mathrm{L}$, the energy required for feeding is balanced by the energy derived from feeding [18].

\section{DISCUSSION}

The mathematical model developed in this paper was used to predict trace metal exposure rates via filter feeding under a variety of conditions. For all conditions considered, predicted $\mathrm{Cr}$ and $\mathrm{Pb}$ exposure occurred predominantly through ingestion of suspended solids, whereas predicted $\mathrm{Cu}$ and $\mathrm{Zn}$ exposure occurred through ingestion of both suspended solids and $S$. platensis. On the basis of metal concentrations in suspended solids, predicted metal ingestion rates via filter feeding were lower than reported avian no observable adverse effects levels (NOAEL) for all of the trace metals except $\mathrm{Cr}$, which was only slightly higher than its NOAEL (Table 4, case 1). On the basis of average sediment metal concentrations, predicted $\mathrm{Cu}$ and $\mathrm{Zn}$ exposure rates increased slightly relative to that predicted based on suspended solids metal concentrations, whereas the $\mathrm{Pb}$ exposure rate doubled and $\mathrm{Cr}$ exposure increased by a factor of six (Table 4, case 2). In this case, $\mathrm{Cu}$ exposure rates were still much lower than its NOAEL for birds [19], Pb and $\mathrm{Zn}$ 

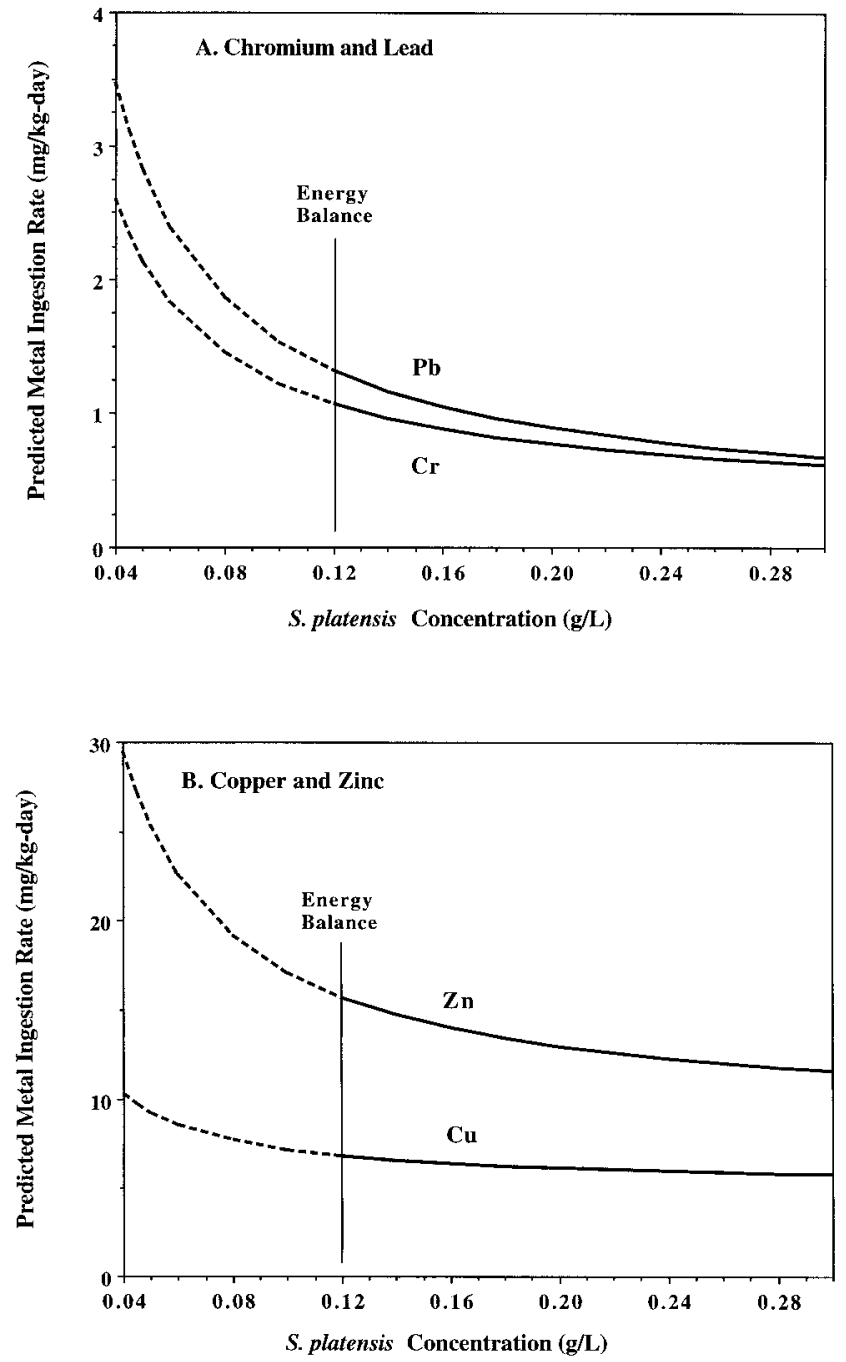

Fig. 6. Predicted toxic metal ingestion rates as a function of suspended Spirulina platensis concentration $(\mathrm{pH}=10.0$, total suspended solids $=1.2 \mathrm{~g} / \mathrm{L})$ : Chromium and lead $(\mathbf{A})$; copper and zinc $(\mathbf{B})$.

exposure rates were slightly higher than their NOAELs, and $\mathrm{Cr}$ exposure rates were much higher than the NOAEL for $\mathrm{Cr}$ (Table 4). Use of average metal concentrations in sediments is conservative because much higher metal exposure rates would be calculated based on maximum metal concentrations of the concentration ranges observed (Table 3 ). The observed ranges in metal sediment concentrations were primarily due to spatial variability, and it is likely that flamingos would be exposed to the higher levels when feeding at certain locations.

Decreases in S. platensis concentrations in the lake could significantly increase the calculated exposure rates. Thus, when $S$. platensis concentrations decline, the flamingos would experience nutritional stress at the same time that their uptake of toxic metals is increasing. For example, consider a $S$. platensis concentration of $0.06 \mathrm{~g} / \mathrm{L}$ with metal concentrations calculated based on average sediment concentrations. In this scenario, predicted $\mathrm{Cu}$ exposure rates are still lower than the $\mathrm{Cu}$ NOAEL, but predicted exposure rates of $\mathrm{Cr}, \mathrm{Pb}$, and $\mathrm{Zn}$ are all higher than their NOAELs (Table 4, case 4). Again, higher exposure rates could be possible at locations with above average trace metal sediment concentrations. These results indicate that changing conditions that reduce $S$. platensis con- centrations could significantly increase metal exposure rates, and this phenomenon provides a possible explanation for the observed episodic flamingo die-offs.

Trace metal exposure rates predicted by the model developed here indicate that toxic trace metals (especially $\mathrm{Cr}$ ) could potentially result in flamingo deaths at Lake Nakuru. However, this model only predicts total trace metal ingestion rates and does not consider uptake in the digestive tract or toxicity data for lesser flamingos. Further research is needed in developing toxicodynamic models for these trace metals before definitive conclusions on the cause of the previously observed flamingo die-offs can be made. It would be particularly informative to determine the phase distribution of trace metals under the more acidic conditions found in the flamingo digestive tract. Nonetheless, these initial results suggest that it would be prudent to take steps to reduce the input of $\mathrm{Cr}$ to Lake Nakuru.

Acknowledgement-Thauthors are grateful for field assistance from Kara J. Hagedorn and for the input of William C. Ghiorse and Michael L. Shuler. Financial assistance was provided through the World Wildlife Fund and an EPA Graduate Fellowship to Y. Nelson. The authors are also grateful for the use of laboratory facilities provided by the Town of Nakuru.

\section{REFERENCES}

1. Motelin GK, Thampy RJ, Ndetei R. 1995. The mysterious lesser flamingo deaths in Lake Nakuru: A cross-sectional ecotoxicological study of the potential roles of algal toxins, heavy metals and pesticides. Report. World Wildlife Fund, Nakuru, Kenya.

2. Jenkin PM. 1957. The filter-feeding and food of flamingos (Phoenicopteri). Philos Trans R Soc Lond B Biol Sci 240:401493.

3. Brown LH. 1955. A Flamingo Mystery Solved-Nesting Grounds of the Lesser Flamingo on an East African Soda Lake. Country Life, London, UK, pp 164-167.

4. Brown L. 1973. The Mystery of the Flamingos. East African Publishing House, Nairobi, Kenya.

5. Vareschi E. 1978. The ecology of Lake Nakuru (Kenya). I. Abundance and feeding of the Lesser Flamingo. Oecologia 32:11-35.

6. Gromme OJ. 1930. Lake Nakuru. Yearbook 1928 Public Museum of Milwaukee, Vol 8. The Museum, Milwaukee, WI, USA, pp 429-444.

7. Ridley MW, Moss BL, Percy RC. 1955. The food of flamingoes in Kenya Colony. J East Afr Nat Hist Soc Nat Mus 22:147-158.

8. Kilham P. 1971. Biogeochemistry of African lakes and rivers. $\mathrm{PhD}$ thesis, Duke University, Durham, NC, USA.

9. Livingstone DA, Melack JM. 1984. Some lakes of subsarahan Africa. In Taub FB, ed, Lakes and Reservoirs. Elsevier, Amsterdam, The Netherlands, pp 467-497.

10. Balistrieri LS, Murray JW. 1983. Metal solid interactions in the marine environment: Estimating apparent equilibrium binding constants. Geochim Cosmochim Acta 47:1019.

11. Sigg L. 1987. Surface chemical aspects of the distribution and fate of metal ions in lakes. In Aquatic Surface Chemistry: Chemical Processes at the Particle-Water Interface. John Wiley \& Sons, New York, NY, USA, pp 319-349.

12. Muller B, Sigg L. 1990. Interaction of trace metals with natural particle surfaces: Comparison between adsorption experiments and field measurements. Aquat Sci 52:75-92.

13. Botelho CMS, Boaventura RAR, Gonclaves MLSS, Sigg L. 1994. Interactions of lead with natural river water. II. Particulate matter. Sci Total Environ 151:101-112.

14. Pettine M, Camusso M, Martinotti W, Marchetti R, Passino R, Queirazza G. 1994. Soluble and particulate metals in the Po River: Factors affecting concentrations and partitioning. Sci Total Environ 145:243-265.

15. Pavlou SP. 1987. The use of equilibrium partitioning approach in determining safe levels of contaminants in marine sediments. In Fate and Effects of Sediment-Bound Chemicals in Aquatic Systems, Pergamon, New York, NY, USA, pp 388-412.

16. American Public Health Association, American Water Works As- 
sociation, and Water Pollution Control Federation. 1995. Standard Methods for the Examination of Water and Wastewater, 19th ed. American Public Health Association, Washington, DC.

17. Melack JM. 1988. Primary producer dynamics associated with evaporative concentration in a shallow, equatorial soda lake (Lake Elementaita, Kenya). Hydrobiologia 158:1-14.
18. Pennycuick CJ, Bartholomew GA. 1973. Energy budget of the lesser flamingo (Phoeniconaias minor Geoffroy). E Afr Wildl J 11:199-207.

19. Sample BE, Opresko DM, Suter GW II. 1996. Toxicological Benchmarks for Wildlife, 1996 Revision. ES/ER/TM-86/R3. Oak Ridge National Laboratory, Oak Ridge, TN, USA. 